This is a postprint version of: Díez Medrano, Juan, Cortina, Clara, Safranoff, Ana and Castro-

Martín, Teresa (2013). "Euromarriages in Spain: Recent trends and patterns in the context of

European integration", Population, Space and Place, 20 (2): 157-176

The final publication is available at https://doi.org/10.1002/psp.1774

\title{
Euromarriages in Spain: Recent trends and patterns in the context of European integration
}

Juan Díez Medrano, Clara Cortina, Ana Safranoff, and Teresa Castro-Martín ${ }^{1}$

\begin{abstract}
This article examines recent trends and patterns in binational marriages between European citizens in Spain over a twenty-year period and the socio-demographic profile and nationality composition of these binational marriages. The analysis relies on aggregate marriage statistics and on marriage register microdata for 2008-2009. We use odds ratios to monitor trends and characteristics of binational marriages and multinomial regression to further examine the sociodemographic profile of these couples. The analysis of marriage records reveals only a modest rise in Euromarriages over the 1990-2009 period. This moderate increase in Euromarriages points towards a weak social impact of the European Single Market. Moreover, the analysis also suggests that binational marriages more often involve lesser educated than more educated individuals. Finally, findings on the social and nationality composition of binational marriages conform to theoretical predictions drawn from the literatures of marriage markets, endogamy, and social hypergamy. They show that the affinity between Spaniards and EU-15 citizens is lesser than that between Spaniards and Non-Europeans (i.e. Latin Americans). They also show that patterns of binational marriages are highly gender-specific. While the affinity between Spanish women and EU-15 men is higher than the affinity between Spanish women and "new" European men, the affinity between Spanish men and "new" European women is higher than the affinity between Spanish men and EU-15 women.
\end{abstract}

Keywords: intermarriage, binational marriages, European Union, European integration, Spain.

\footnotetext{
${ }^{1}$ Juan Díez Medrano (Catedrático Rafael del Pino at the Universidad Carlos III Madrid e Institut Barcelona d' Estudis Internacionals--IBEI); Clara Cortina, (Postdoctoral researcher at the Institut Barcelona d'Estudis Internacionals--IBEI-- and CSIC);Ana Safranoff ( $\mathrm{PhD}$ candidate at the Universitat Pompeu Fabra) ; Teresa Castro Martín (Profesora de Investigación at the Centro de Ciencias Humanas y Sociales, CSIC). This article is part of the project "Toward a European Society: Single Market, Binational Marriages, and Social Group Formation in Europe -EUMARR-

" (http://www.ibei.org/projects/eumarr/). It has been written with support from the European Science Foundation (Project 09-ECRP-044), from the Spanish Ministry of Economy and Competitivity (EUI201004221 and CSO2009-11883), and from the Programa de Cátedras de Excelencia de la Fundación Rafael del Pino.
} 


\section{Introduction}

This article focuses on the impact of European integration on the transnationalization of life trajectories, social interaction, and personal relationships, by examining recent trends in binational marriages between European citizens in Spain and the socio-demographic characteristics of partners to these marriages. The literature on intermarriage has dealt primarily with intermarriage between lower class immigrants (or ethnic and racial minority groups) and members of host societies (or dominant ethnic and racial groups). Studies in this tradition have generally assessed the level of integration of immigrants and their descendents and measured social distance between ethnic groups in a given society (Qian and Lichter, 2007). Research in Europe is no exception (Varro, 1995). The majority of studies have focused on marriage between EU and non-EU citizens and have lacked a European-wide dimension (e.g. see González-Ferrer, 2006; Schroedter, 2006; Kalmijn and Van Tubergen, 2007; Braun and Recchi, 2008; Cortina et al., 2008). When they have encompassed Europeans, the usual target of study has been the cohorts of low-skilled labor migrants that left Southern Europe in the 1950s and early 1960s and their offspring. It is only very recently that researchers have started to pay attention to binational marriages between Europeans as an emerging social phenomenon that reflects the intensification of social group ties throughout Europe (Braun and Recchi, 2008; Gaspar, 2009; Koelet et al., 2011; Lanzieri, 2011), but empirical studies are still lacking. This article, like the rest of articles in this volume, is a first step toward filling this research gap.

The freedom of movement and residence within a large number of European countries since the early 1990s, EU policies promoting cross-border mobility to study and work, the increasing interconnectivity, and the globalization of lifestyles and behaviors, lead to the expectation of a concomitant rise in the number of binational marriages between Europeans. Spain became a member of the European Union in 1985 and since the late 1990s it has been a prime destination for migrants from all over the world (Arango and Finotelli, 2009), including Central and Eastern Europe (Stanek, 2009). Spain is also one of the world's leading tourist destinations (World Tourism Organization, 2011). Last but not least, Spain has been a top choice for Erasmus/Socrates students over the years: in the academic year 2009/2010 Spain received more than 27.000 students from other EU countries, slightly more than the 
next two countries, France and Germany ${ }^{2}$. Spain is thus an interesting case study for the analysis of the impact of European integration on trends in European intra-marriage (Gaspar, 2008) or Euromarriages. This article's main objective is to assess whether the process of social integration that is taking place in Europe has indeed translated into a significant rise in the number of Euromarriages in Spain.

The recent literature on the sociological impact of European integration has also emphasized that European integration benefits mainly the better educated segments of the population, through expanding their mobility patterns and their connectivity opportunities (Gabel, 1998; Favell, 2008; Fligstein, 2008). The better-educated segments of the population also tend to have a more cosmopolitan outlook and should be more open to romantic partnerships with individuals from other nationalities. One would thus expect the number of European binational marriages in the last two decades to have increased more among the better-educated segments of the population than among the lesser educated ones. Therefore, this article's second objective is to examine the socio-demographic profile of these Euromarriages and test empirically the validity of this expectation.

Finally, the sociological literature on European integration is interested in the impact that it may have on the formation and social and cultural characteristics of transnational social groups (Díez Medrano, 2010, 2011). Families resulting from binational marriages are both an expression of and a vehicle toward the formation of these social groups, whose social and cultural characteristics are surely influenced by the nationalities that come together to form them. Within the limits of the available data, this article thus examines and explains the relative prevalence of different nationality combinations in Spain's binational marriages. We examine these contrasts under the light of theoretical expectations drawn from the literature.

The article is structured as follows: first, we review the literature on the expected implications of the creation of the European Single Market in the early 1990s and lay-out hypotheses on the prevalence and characteristics of binational marriages between Europeans; second, we present the Spanish data sources and methods used for the analysis; third, we contrast the different hypotheses sketched through descriptive and statistical analysis of the sociodemographic characteristics of these Euromarriages in recent years. Finally, the article's last section summarizes the results and draws implications for the study of the social dimension of European integration.

\footnotetext{
${ }^{2}$ http://ec.europa.eu/education/erasmus/doc920_en.htm\#1
} 


\section{Background: Intra-EU migration and the diversification of the marriage market}

The main non-economic reason for the creation of the EU Single Market in 1993 and the Schengen area in 1995 was the promotion of mobility among Europeans ${ }^{3}$. In particular, both the European Commission and the scholarly community assumed that a borderless Europe would encourage well-educated European professionals to move across Europe in search of the best available opportunities (Recchi and Favell, 2009). The European Commission's hope was that mass mobility would translate into stronger cross-border bonds and supranational forms of identification. Similar motives underlie the creation of the Erasmus program for student exchange across Europe. The European Commission's ultimate expectation was that cross-border bonds and supranational forms of identification would in turn create "diffuse" support for further European integration among the population (see Favell, 2008; Calligaro, 2011; Favell and Guiraudon, 2011).

Almost twenty years after the creation of the Single Market, these expectations remain largely unfulfilled. Although the Single Market and EU programs like Erasmus expanded considerably the mobility opportunities for workers and students, intra-EU migration increased only moderately before the end of the millennium and migration from non-EU countries outpaced migration from EU countries. Data compiled by Recchi (2005) for the period 1990-2000 show indeed that while the percentage of non-EU migrants to the EU increased by $33 \%$, the percentage of EU migrants merely increased by $10 \%$. In fact, most intra-European migration in Western Europe took place before the Single Market and Schengen, during the 1950s and 1960s, as workers from Southern Europe migrated to the prosperous North in search of better economic opportunities. The 2004 and 2007 EU enlargements to Central and Eastern Europe, however, have somewhat contributed to redress the situation. Despite long transition periods for the free mobility of citizens from the new member states as part of the EU enlargement treaties, the waving of these transition periods by some countries and the early lifting of barriers in others have contributed, directly and indirectly, to facilitate a large East-West flow of migrants in recent years. This East-West flow has significantly increased the co-presence of young Europeans from different nationalities. In all, the EU27 population with foreign nationality reached $6.5 \%$ in 2010 and the share of citizens from another EU country represented $38 \%$ of the total foreign population

\footnotetext{
${ }^{3}$ The creation of the Single Market in 1993 aimed at eliminating all remaining barriers to the free movement of goods, capital, services and people across EU member states.
} 
(Eurostat Statistics Database) $)^{4}$. The corresponding figures for Spain were 12\% and $41 \%$. Although long-term residential intra-EU mobility has not met the European Commission's expectations, a growing number of Europeans now live in a different country from the one in which they were born. Furthermore, the increased affordability of travel across borders that has resulted from the liberalization of the air transportation industry has fostered new forms of trans-European mobility (short-term, circular, seasonal) and has thus led to an exponential increase in the opportunities for contact between citizens of different European states.

\section{II-1. Partner availability and Binational Marriages}

This article focuses on Spain, in order to examine the impact of the Single Market and rising international mobility on binational marriages between Europeans. The article's first and main hypothesis is that the European Single Market has translated into a gradual increase in the frequency of binational marriages and cohabiting unions between Europeans (H1). Indeed, as the literature on intermarriage emphasizes, individual preferences about spouse selection only become activated within a specific mating opportunity context, such that the number and characteristics of potential male and female spouses in a defined area strongly determine partner choices and the resulting couples (Blau, 1977; Blau and Schwartz, 1984). Although Internet facilitates a de-coupling of interpersonal contact and place (Niedomysl et al., 2010; Glowsky, 2011), the vast majority of couples still follow from face-to-face interaction (Haandrikman and Hutter, 2012). We thus expect that the elimination of barriers to movement through the creation of the Single Market has translated into greater mobility across Europe, which has in turn propitiated an increase in the number of binational marriages between Europeans.

II-2. Skills, Migration, and Trends in the Relative Incidence of Binational Marriage among Highly- and Lesser- Educated Population Segments

The sociological literature on intra-European mobility has predominantly featured highly educated migrants. Whether we think of the mobility of professionals within transnational corporations (Salt, 1991), the job and career opportunities opened for the European Union elites at the European Commission (Georgakakis, 2012), the mobility of young, unattached,

\footnotetext{
${ }^{4}$ http://epp.eurostat.ec.europa.eu/portal/page/portal/population/data/database
} 
professionals drawn by the cosmopolitan character of cities like London, Brussels, or Amsterdam (Favell, 2008), the mobility of scientists across European Union academic institutions (Ackers, 2004) or, finally, the short-term mobility and transnational personal networks of Erasmus students (Fligstein, 2008), the focus is always on those with high cultural capital (see also Recchi, 2005; Recchi and Favell, 2009). This focus is in part justified by the relative novelty of this type of mobility and implicitly draws on pre-EU enlargement human capital economic models that conclude that the highly skilled are those who benefit most from the European Single Market (e.g. Gabel, 1998). The reasoning is simple: if it is the highly skilled that benefit the most, it is they who should move most often. The secondorder sociological prediction that follows from this expectation is that in Spain, just like in other EU states, the European Union Single Market has led to a greater increase in Euromarriages among highly educated individuals than among lesser educated ones (H2a). Further theoretical backing for this empirical prediction comes from the literatures on cosmopolitanism, European identity, and ethnic prejudice, which argue and empirically demonstrate that highly educated individuals are more open to other cultures and to other identifications than are lesser educated ones (e.g. Gordon, 1964; Inglehart, 1977; Lieberson and Waters, 1988; Kalmijn, 1998). The observed endogamy observed and documented for national and ethnic groups should therefore be less strong among the more educated than among the lesser-educated segments of society.

The economic logic that underlies the expectation of greater geographic mobility among the highly skilled than among the lesser skilled segments of the population has been partly contradicted by the evidence of very low intra-European mobility in the ten years that followed the creation of the European Single Market and the evidence of much greater EastWest intra-European mobility since the enlargement processes to Central and Eastern Europe. Because of the wealth and socioeconomic gulf that exists between Western and Eastern Europe, especially when one considers the newest members, Romania and Bulgaria, these geographical trans-European mobility patterns suggest that it is the lesser educated and not the more educated workers who have taken advantage of the greater opportunities for mobility opened by the Single Market. Although greater mobility by the lesser educated than by the more educated may not compensate for the greater openness to others expected among the latter and for the greater opportunities for short-term mobility and international contact that the latter enjoy because of their greater economic resources, it opens up the possibility that increases in the frequency of binational marriage between Europeans have been greater 
among the lesser than among the more educated (H2b).

\section{II-3. Nationality Combinations in Binational Marriages}

The recent literature on the sociological impact of European integration (e.g. Recchi, 2005; Recchi and Favell, 2009) has prioritized the study of transnational mobility per se and, consequently, does not provide further insights as to other aspects of marriage between Europeans than the ones discussed in the paragraphs above. If one is seriously interested in social group formation in Europe, however, and more specifically, in the potential development of transnational bonds of solidarity that could eventually lead to the division of national social groups into cosmopolitan and local segments (Díez Medrano, 2008, 2010), one must empirically examine these binational marriages up close. In particular, and within the limitations of the data available, this article examines prevalent nationality combinations in binational marriages. The combination of specific nationalities ought to translate into specific processes of cultural hybridization susceptible of being transmitted intergenerationally (at least in part), which would in turn shape the lifestyles, values, and identifications of the cosmopolitan segments of national social groups across Europe. In this article, we focus mainly on the distinction between marriages between Spaniards and EU15 nationals and Spaniards and nationals from the states that entered the EU in the recent 2004 and 2007 enlargement processes. We also assess the prevalence of these marriages compared to those between Spaniards and non-European citizens.

\section{Marriage Markets}

Various factors lead to the predominance of particular nationality combinations in binational marriages. A major one is the structure of the marriage market. Marriage theory states that dominant choices are largely driven by partner availability (Blau, 1977; Blau and Schwartz 1984). This includes the relative presence of various nationalities, their sex-ratios, and their marital status composition. Population register data for Spain in the 1991-2009 period show a spectacular rise in the percentage of foreign nationals in Spain. Although there has been a large influx of Europeans, the majority of whom came from Romania, it pales in comparison with the number of migrants from outside Europe. Also, although the sex-ratio among the different immigrant groups tends to be the same (about 20\% more men than women), according to the 2007 Spanish Immigrant Survey (Reher and Requena, 2009), Europeans have partners upon arrival (43.7\%) much more often than have non-Europeans (39.8\%), and New 
Europeans (i.e. from Central and Eastern EU member states) much more so than EU15 Europeans $(51.9 \%$ versus $31.9 \%)$. This demographic information, together with the demonstrated significant role of co-presence in determining partner choices, lead to the prediction that binational marriages between Spaniards and non-Europeans are more frequent than those between Spaniards and Europeans and that marriages between Spaniards and EU15 citizens are more frequent than marriages between Spaniards and New Europeans.

\section{Values and Endogamy}

Intermarriage theory leads to the expectation that endogamous preferences in mate selection, more pronounced among the lesser educated than among the more educated segments of the population, lead to Spaniards getting married to people from countries whose cultures are similar to Spain's (e.g. because they share a language, a religion, or a particular world outlook) more often than to people from countries whose cultures strongly differ from Spain's (e.g. Sánchez-Domínguez et al., 2011; Kalmijn, 1998). For instance, Spaniards, EU15 citizens, New Europeans, and Latin Americans share a Christian religion, despite denominational differences. Religious affinity is of course greater with Catholic Latin Americans and with citizens from predominantly Catholic EU-15 countries (e.g. Italy, France, Portugal) than with citizens from Protestant (e.g. Britain) or Orthodox European countries (e.g. Romania, Bulgaria). Also, Spaniards share the same language with the majority of Latin American immigrants and they share a Latin language with Southern European countries and with Romania. Finally, according to the World Values Study, the average Spaniards' values are slightly closer to those prevalent in the EU15 countries (especially those well represented in Spain, e.g. Italy, France, Great Britain, Germany) than to those prevalent in the new EU member states (i.e. Bulgaria, Romania) and in non-European countries (including Latin America, with the exception of Argentina). Since overall cultural proximity in the end depends on several cultural dimensions, predictions about the most prevalent nationality combinations in binational marriages are risky. Nonetheless, on the basis of the descriptive information above, it would seem that Latin Americans and Southern Europeans are culturally closer (e.g. religion, language, values) than are New Europeans and, especially, North Africans. The marriage affinity between Spaniards and Latin Americans and between Spaniards and EU15 Europeans should thus be greater than that between Spaniards and other groups of immigrants (on endogamy in Spanish binational marriages see Sánchez-Domínguez et al., 2011). 


\section{Homogamy and Hypergamy}

Marriage theory also states that partner choice is generally driven by homogamy (Schoen and Wooldredge, 1989; Mare, 1991; Blackwell, 1998), with women showing a slight tendency to move up socially through marriage -hypergamy-(Burchinal, 1964; Zelditch, 1964). The extent of homogamy and hypergamy depends on the measures one uses (e.g. class of origin, individual socioeconomic achievement, educational attainment). Homogamy is usually explained with reference to contact opportunities between people with the same social background, interest in social reproduction among privileged groups in society, social pressures from significant others, and a human tendency for people who are similar to like one another (Schoen and Wooldredge, 1989). Meanwhile, hypergamy in women's marriage choices stems from a combination of factors, whose relative importance varies across time and space. One such factor is the stratification system: If one measures social position through individual characteristics and women's access to higher education or to well-paid occupations is more restricted than men's, it is to be expected that many men of higher socioeconomic position will either remain single or else find partners among women of a lower socioeconomic status. Another factor is patriarchy, which at the level of marriage expresses itself in men striving to be the dominant partner in the couple.

In recent years, scholars have noted two related developments in advanced economies, with implications for assortative matching: the equalization of men's and women's individual social achievement and challenges to traditional gender roles, with women striving for more equality in interpersonal relations with men. Female educational attainment now exceeds that of males (Esping-Andersen, 2009) and this means that hypogamous assortative matching, where women have more education than their male partners, has become a widespread phenomenon (Esteve and Cortina 2006). Men, however, are still over-represented in better-paid and more prestigious occupations. This leads to the expectation that, viewed from this structural dimension, hypergamous assortative matching is still prevalent. This social context has implications for the development of predictions concerning gender differences in the combination of nationalities in binational marriages. The nationality groups that ground our empirical analysis can be ranked from higher to lower average levels in terms of educational and occupational attainment: EU15, Spaniards, New Europeans, Non-Europeans (with the latter two groups at comparable levels and with educational contrasts narrower than occupational ones). Regardless of internal group diversity, this fact, combined with the general stigma attached to immigrants, especially if of 
low socioeconomic status, results in a ranking of immigrant nationality categories, from higher-status EU15 citizens to lower-status New Europeans and Non-Europeans.

Higher educational attainment among women than among men in advanced economies leads to the expectation that women display a greater propensity to get married to partners with lower educational attainment (hypogamy) than men and, through aggregation, with partners from nationality groups with lower average educational levels. In Spain, this leads to the following hypotheses: 1) EU15 women's propensity to get married to Spanish, New European, and Non-European men is greater than EU15 men's propensity to be married to Spanish, New European, and Non-European women; 2) Spanish women's propensity to get married to New European and Non-European men is greater than Spanish men's propensity to be married to New European and Non-European women.

As we point out above, however, educational out-performance has not led women to catch-up with men in terms of career opportunities and salaries. This means that a pure structural marriage market logic, focused on career and income, leads to predictions that are just the opposite to those in the previous paragraph above: 1) EU15 men's propensity to get married to Spanish, New European, and Non-European women is greater than EU15 women's propensity to be married to Spanish, New European, and Non-European men; 2) Spanish men's propensity to get married to New European and Non-European women is greater than Spanish women's propensity to be married to New European and Non-European men. Which of the two logics -the educational or the economic logic- in the end prevails, thus driving observed gender differences in nationality combinations, depends on the relative magnitude of gender inequalities in education and career/income opportunities and on men's and women's relative priority attached to education and income when making partner choices.

A consideration of patriarchy and its implications for assortative matching, however, tilts the balance toward the second set of predictions above. There is a vast literature that demonstrates the existence of a positive association between women's educational attainment and their assertiveness vis à vis men, which includes a challenge to traditional gender roles. Traditional men in advanced economies, where women's average level of educational attainment is highest, may thus find it increasingly difficult to find women in their own group who are supportive of traditional gender roles. The opportunity to find women who value traditional gender roles is greater among nationality groups where these values are more prevalent. Similarly, it is conceivable that many women in lower status nationality groups, especially those with higher levels of education, will show a greater preference for men from 
higher-status nationality groups than from their own group, partly for material reasons, but also because men in these higher-status nationality groups hold, on average, more egalitarian values regarding gender roles that do men in their own nationality group. Based on our ranking of different immigrant groups by status and on comparative literature based on the World Values Survey (Inglehart and Norris, 2003), which shows that gender equality values are more prevalent in EU15 countries than in New European and Non-European countries, one would thus predict the following: 1) EU15 men's propensity to be married to Spanish, New European, and Non-European women is greater than EU15 men's propensity to be married to Spanish, New European, and Non-European women; 2) Spanish men's propensity to be married to New European and Non-European women is greater than Spanish women's propensity to be married to New European and Non-European men. Since this cultural prediction overlaps with the structural prediction that results from the analysis of gender differences in career/income opportunities, we view this as the most promising hypothesis concerning gender differences in nationality combinations in binational marriages.

The discussion above thus allows for the formulation of the third, fourth, and fifth hypotheses guiding this research article, which concern the relative prevalence of marriages between men and women of different nationalities and the relative marriage affinity observed between nationalities. The partner availability and the endogamy theses, combined with the demographic, socio-economic, and cultural profile of foreigners in Spain, lead to the prediction that binational marriages between Spaniards and Latin Americans are more frequent than binational marriages between Spaniards and EU15 nationals and that binational marriages between Spaniards and EU15 nationals are slightly more frequent than marriages between Spaniards and New Europeans (H3). Also, the endogamy thesis applied to the Spanish socio-economic and demographic reality leads to the prediction that affinity between Spaniards and Latin Americans is greater than affinity between Spaniards and EU-15 citizens, whereas affinity between Spaniards and EU-15 members is greater than affinity between Spaniards and New Europeans (H4). Finally, in the Spanish context, the hypergamy thesis and a cultural argument focused on gender roles lead to the prediction that there is greater marriage affinity 1) between Spanish women and EU-15 nationals than between Spanish men and EU-15 women, 2) between New European women and Spanish men than between New European men and Spanish women, and 3) between Non European women and Spanish men than between Non European men and Spanish women (H5). 
Summary of the main research interests and hypotheses

\begin{tabular}{|c|c|}
\hline The Single Market, geographical mobility and Euromarriages \\
\hline H.1. & The Single Market has led to a significant increase in Euromarriages \\
\hline Contrasts in geographical mobility by education and incidence of \\
Euromarriages. \\
\hline H.2. & $\begin{array}{l}\text { a. The incidence of Euromarriages is greater among higher-educated } \\
\text { than among lesser educated individuals. } \\
\text { b. The incidence of Euromarriages is greater among lesser-educated } \\
\text { than among higher educated individuals }\end{array}$ \\
\hline $\begin{array}{l}\text { Context: the combined roles of the marriage market and endogamy on the } \\
\text { nationality combination of Euromarriages }\end{array}$ \\
\hline H.3 & $\begin{array}{l}\text { Binational marriages between Spaniards and Latin Americans are } \\
\text { more frequent than binational marriages between Spaniards and EU- } \\
\text { 15 nationals, and binational marriages between Spaniards and EU-15 } \\
\text { nationals are slightly more frequent than marriages between } \\
\text { Spaniards and New Europeans }\end{array}$ \\
\hline H.4 & $\begin{array}{l}\text { After controlling for the sizes of different nationality groupings, the } \\
\text { marriage affinity between Spaniards and Latin Americans is greater } \\
\text { than the marriage affinity between Spaniards and EU-15 citizens, } \\
\text { whereas the marriage affinity between Spaniards and EU-15 } \\
\text { members is greater than the marriage affinity between Spaniards and } \\
\text { New Europeans }\end{array}$ \\
\hline Hypergamy, Endogamy, and Euromarriages \\
\hline H.5 & $\begin{array}{l}\text { There is greater marriage affinity 1) between Spanish women and } \\
\text { EU-15 nationals than between Spanish men and EU-15 women, 2) } \\
\text { between New European women and Spanish men than between New } \\
\text { European men and Spanish women, and 3) between Non European } \\
\text { women and Spanish men than between Non European men and } \\
\text { Spanish women }\end{array}$ \\
\hline
\end{tabular}

\section{Data and methods}

\section{III.1. Data}

In order to examine trends in intermarriage between Europeans, we rely on official marriage records centralized at the Spanish Statistical Institute. One limitation of restricting our analysis to marriages registered in Spain only is that by design we exclude binational marriages between Spaniards and other Europeans that have been registered in other countries. This may underestimate the incidence of binational marriages. We assume, however, that the propensity to marry abroad has not changed in recent decades and that, consequently, the trend estimates remain unaffected. The analysis is also restricted to heterosexual couples, mainly because same-sex marriages have only been legal since 2005 . The period under study runs from 1989 to 2009. Although a rigorous test of the impact of the EU Single Market on binational marriages demands pre-1989 data, it is only since 1989 
that information allowing for the analysis of intermarriage was collected. Since records of the nationality of the spouses only go back to 1989 whereas information on the country of birth is only available from 2008 onwards, we restrict our definition of binational marriages to the former. Needless to say, the use of nationality is somewhat problematic because of the association between marriage and changes in the nationality status of the partners. In European Union states, however, this is less of a problem because the rate of naturalization of European citizens is relatively low (OECD, 2010). Indeed, European citizens living in EU states other than their own have little to gain in terms of civil, social, and political rights from the adoption of the nationality of the country where they reside. The use of country of birth in the analysis of binational marriages would in fact raise another sort of problem: many residents in Spain born in Germany and France are the offspring of return Spanish migrants and have spent most of their lives in Spain. It would not be appropriate to treat marriages between them and Spanish citizens born in Spain as binational marriages.

In order to examine trends in the frequency of binational marriages among people with different levels of education we combine information on the spouses' nationality with microdata from the marriage register for the period 2008-2009. This source of information shows that EU-15 spouses display higher average levels of educational attainment than do Spaniards, whereas Spaniards display higher average levels of educational attainment than do other Europeans and non-Europeans ${ }^{5}$. One can thus use information on trends in binational marriages between Spaniards and different nationality groups as indirect evidence on the relative frequency of binational marriages across levels of educational attainment. In order to analyze the relative incidence of different nationality combinations in binational marriages, to examine gender differences in these combinations, and to analyze the role of homogamy and hypergamy in binational marriages, we use again microdata on binational marriages for the years 2008 and 2009.

\section{III.2. Methods}

We classify marriages in different categories so as to distinguish international marriages (one or two foreign spouses), binational marriages (spouses with different nationalities) and binational European marriages (marriages between two EU citizens of different nationalities, whether they involve a Spanish partner or not). Because of our interest in the educational and

\footnotetext{
${ }^{5}$ This is especially true among males. The proportion of men with a University degree is $43 \%$ for UE 15 , and $27 \%$ for Spaniards, $14 \%$ for New EU, and $15 \%$ for non-EU. Among females, the proportion with a University degree is $39 \%$ for both EU15 and Spaniards and UE15, 19\% for New EU, and 20\% for non-EU.
} 
occupational profile of European mixed marriages and based on the information reported above on average levels of education for different nationalities, we distinguish two categories of Europeans: "EU-15" and "New EU"7. Citizens in the first group have enjoyed freedom of movement and residence for a longer period, and they often fall into the category of "free movers" -i.e. citizens who migrate for professional or personal reasons instead of out of sheer economic necessity. Conversely, low-skilled labour migration of a traditional sort is largely represented in the second group. The distinction between EU-15 and New EU migrants becomes especially useful when testing the hypergamy hypotheses above.

To monitor trends in the incidence of Euromarriages, the analysis uses absolute numbers and percentages relative to all marriages registered in a given year, by sex and nationality group of the foreign spouse. In order to analyze the relative marriage affinity between nationality groups and to control for group size, marital status composition, and sex ratios across nationalities, we compute odds-ratios as recommended by Kalmijn (1998). Finally, we compute odds-ratios based on microdata from the 2008-2009 marriage registers to examine assortative matching by education within and across nationality groups. We also use 2008-2009 microdata to estimate multinomial logit models for the analysis of the net association between socio-demographic variables and the Spaniards' odds of marrying members of specific nationality groups. The analysis is restricted to the age group 20-49 where most marriages take place. The variables included in the statistical models are those collected on marriage certificates, namely age, marriage order, educational level and occupational status (recoded into two categories: high-skill and low-skill occupations). The models also include an indicator of educational homogamy in order to further examine assortative mating patterns.

\section{Findings}

\section{IV.1. Trends in international marriages and Euromarriages in Spain}

As stated above, migrant flows to Spain accelerated in the late 1990s, leading to a 5 million increase in the stock of foreigners. Spain is currently one of the countries with the largest foreign populations in the European Union, both in absolute and relative terms. In 2010 only

\footnotetext{
${ }^{6}$ Austria, Belgium, Denmark, Finland, France, Germany, Greece, Ireland, Italy, Luxembourg, Netherlands, Portugal, Sweden, United Kingdom.

7 Cyprus, Bulgaria, Czech Republic, Estonia, Hungary, Latvia, Lithuania, Malta, Poland, Rumania, Slovakia, Slovenia. This group includes mainly Romanians and Bulgarians, who joined the EU in 2007.
} 
Germany had a larger number of foreigners and only Luxembourg, Latvia and Estonia ${ }^{8}$ had a higher proportion of foreigners (Eurostat Statistics Database). Figure 1 shows that the number of Europeans residing in Spain is seven times larger than it was ten years ago (it went from 371,000 in 1999 to 2,431,000 in 2009). A large part of this increase is due to the recent rise in immigration from Eastern European countries: whereas the foreign population from EU-15 increased by about 950,000 people, the foreign population from New EU member states increased by about 1,100,000 people. More than two thirds of them are Romanian, despite the fact that Romania only joined the EU in 2007. Although the growth of the European population that resides in Spain has been significant, the most remarkable finding from Figure 1 is the spectacular increase in the number of non-Europeans, which added nearly 3 million to the Spanish population in only a decade. Clearly, much more powerful forces than the creation of the European Single Market in 1993 have driven migration flows to Spain. In 2009, the composition of the foreign population by region of origin was very heterogeneous and much more so than a decade earlier, with Latin Americans and North Africans (especially Moroccans) as the largest non-European groups.

- Figure 1 around here -

The dramatic increase in the numbers of foreigners and the nationality composition of the foreign population have shaped Spain's marriage market. Indeed, whereas the percentage of all marriages involving at least one foreign spouse was $4.4 \%$ in the period 1990 1994, this figure increased to $17.2 \%$ in the period 2005-2009 (Table 1). The large majority of these international marriages were binational (i.e. they involved two persons of different nationality) and included a Spaniard. The article's first hypothesis is supported by the data: the implementation of the European Single Market has led to an increase in the number of Europeans who reside in Spain, which has run parallel to a rise in the number of binational marriages where one of the spouses is European (from 16,317 in 1995-1999 to 27,000 in 2005-2009). Increased co-presence thus translates into more inter-marriage. The rise in the number of Euromarriages, however, stands well below expectations (see Figure 2), which demands clarification. A partial answer to this puzzle is that marriage register data do not fully capture the impact of recent migration on binational couple formation because of increasing nonmarital cohabitation among recent cohorts (Timberlake and Heuveline, 2005;

\footnotetext{
${ }^{8}$ The proportion of foreign citizens in Latvia (17\%) and Estonia (16\%) is particularly large due to the high number of 'recognised non-citizens', mainly former Soviet Union citizens, who are permanently resident in these countries but have not acquired Latvian/Estonian citizenship or any other citizenship.
} 
Domínguez and Castro-Martín, 2008). Indeed, the 2001 Spanish population census shows that in the age range 20 to 49 , the proportion of consensual unions among international couples was about $20 \%$. As of $2007,27 \%$ of international couples were cohabiting, according to the Spanish Immigration Survey. Europeans, both from EU-15 and New EU countries, as well as Latin Americans, are the foreign groups with the highest levels of nonmarital cohabitation (Cortina et al., 2010).

- Figure 1 around here -

Another potential explanation for the gap between the high volume of European migration and the relatively low frequency of binational marriages involving a European is that more than a third of the foreign EU-27 population that resides in Spain is of retirement age or too young to get married. Also, as stated above, although the bulk of new migrants coming from Europe were people in their twenties and in their thirties, a large proportion of them already had a partner upon arrival (about $44 \%)^{9}$.

- Table 1 about here -

Still, the most likely explanation for why the significant increase in the EU-15 population did not translate into a commensurate rise in binational marriages between Europeans is that the increase in the foreign population from other areas of the world in that same decade was much greater and therefore there was much more competition in the marriage market. In fact, the proportion of total marriages involving a non-European partner rose from $2.6 \%$ in $1990-1994$ to $11.9 \%$ in 2005-2009 (see Table 1).

\section{IV.2. Educational Attainment and Trends in Binational Marriages}

In the last decade the increase in the number of binational marriages between Europeans has been mainly driven by New Europeans, whose average level of education is significantly lower than that of EU-15 Europeans. The number of binational marriages involving a New European increased from 641 in 1990-1994 to 12,670 in 2005-2009, whereas the number of binational marriages involving an EU-15 European increased from 15,430 to 24,962 during the same period (see Table 1). Since 2000, there have been more binational

\footnotetext{
${ }^{9}$ It is worth noting that the proportion of EU-15 citizens who already had a partner when they arrived in Spain would be much higher were we not restricting our analysis to migrants between the ages of twenty and forty-nine. Indeed, many EU-15 migrants were retirees who came with their spouses (Esteve and Cortina, 2011)
} 
marriages involving Romanian citizens than binational marriages involving any other foreign nationality. In fact, if one considers the entire 1990-2009 period, Spanish men have married more Romanian women than women of any other European nationality, despite the fact that such marriages were uncommon before 2000. These findings support $\mathrm{H} 2 \mathrm{~b}$ and contradict $\mathrm{H} 2 \mathrm{a}$.

One explanation for the observed trends is that migration from low-skilled workers from the new EU member states has exceeded expectations derived from economic arguments made before the EU enlargements to Central and Eastern Europe (see Gabel, 1998). In the new context of a much more economically diverse European Union, globalization, and deregulated labor markets, the economic pay-offs to low-skilled migration within Europe are much higher than they were in the mid-1990s. Therefore, one would expect at least as much low-skilled as high-skilled intra-European mobility, with its resulting impact on marriage rates. Indeed, migration to Spain from the new EU states in the last two decades exceeded by about 150,000 people migration from the EU-15 member states. In fact, much of this migration took place even before the official dates for enlargement and the lifting of barriers to movement to citizens from the new EU member states. Because of this, the increase in the number of binational marriages involving a New European was almost as high between 1995 1999 and 2000-2004 as between 2000-2004 and 2005-2009.

\section{IV-3. Nationality Combinations in Binational Marriages}

The previous section has already discussed contrasts in the composition of binational marriages by nationality. We now move to directly examine the article's hypotheses concerning the national composition of binational marriages. In agreement with our third hypothesis, the most frequent type of binational marriage involves Latin American foreign citizens. Latin Americans are the most numerous foreign population in Spain, they have a greater propensity than other nationality groups to lack a partner at the moment of migration, and speak Spanish. Also as expected, there are slightly more binational marriages between Spaniards and EU-15 Europeans than between Spaniards and New Europeans (see Table 1). Not only is the foreign EU-15 population slightly more numerous than is the foreign population from the new EU member states, but they come more often without a partner and they are more similar to Spaniards in their cultural outlook.

The fourth hypothesis refers to the role of cultural endogamy in binational marriage choices in determining the relative affinity between the different nationality groups that live 
in Spain. To contrast this hypothesis we examine odds-ratios for marriages between Spaniards and EU-15 citizens and between Spaniards and New Europeans corresponding to three time periods: 1990-1991, 2000-2001, and 2008-2009 (Table 2). The odds-ratio for the SpanishEU15 combination represents the odds of a marriage between a Spaniard and a EU-15 citizen relative to the odds of a marriage between a non-Spaniard and a EU-15 citizen. The oddsratio for the Spanish-New European combination represents the odds of a marriage between a Spaniard and a New European relative to the odds of a marriage between a non-Spaniard and a New European. In order to interpret the odds-ratios, it is important to keep in mind that over time the population of foreigners living in Spain has changed in size and internal composition and that there is variation in the marriage affinity between the nationality groupings that form the non-Spaniard category (EU-15, New European, Non-European).

- Table 2 about here -

Generally speaking, the values for the odds-ratio are well below 1, which indicates a great deal of endogamy across nationalities. Aside from this commonality, the odds-ratio values change over time. In 1990-1991, half the foreign population residing in Spain included EU-15 citizens and there were hardly any New Europeans. The odds-ratio of a marriage between a Spaniard and a EU-15 citizen was similar for men and women, and so was the odds-ratio of a marriage between a Spaniard and a New European compared to a nonEuropean. Meanwhile, the odds-ratio for a marriage between a Spaniard and a EU-15 citizen was higher than the odds-ratio for a marriage between a Spaniard and a New European and a marriage between a Spaniard and a Non-European. In 2000-2001, the foreign population residing in Spain had increased by about 250,000 non-Europeans and by a mere 75,000 EU27 Europeans. Within the EU-27 population, there were still very few New Europeans (around 15,000). In this context, the odds-ratios of a marriage between a Spaniard and a EU15 citizen differed by gender: it was considerably higher for marriages between Spanish women and EU-15 men. The odds-ratios of a marriage between a Spaniard and a nonEuropean were slightly higher for Spanish men than for Spanish women, but they were both higher than the odds-ratio for marriages between a Spaniard and a new European. Finally, in 2008-2009, the foreign population living in Spain had increased dramatically and its composition had changed significantly, with the number of New Europeans almost matching the number of EU-15 Europeans. In this new context, the odds-ratio of a marriage between a Spanish woman and a EU-15 man was still higher than the odds-ratio of a marriage between 
a Spanish man and a EU-15 woman. One novelty in 2008-2009 is that the odds-ratio of a marriage between a Spanish man and a New European woman was also much higher than the odds-ratio of a marriage between a Spanish woman and a New European man. In fact, the odds-ratio of a marriage between a Spanish woman and a EU-15 man was about as high as the odds of a marriage between a Spanish man and a New European woman. Also, the oddsratios for marriages between Spanish men and women and non-Europeans had noticeably increased, with the Spanish men's ratio reaching 0.25 and the Spanish women's reaching 0.21 .

On the whole, these findings support the endogamy hypothesis, H4. Spaniards marry predominantly among themselves and then with two nationality groups that are very close culturally, non-Europeans (which include a majority of Latin Americans) and EU-15 men ${ }^{10}$. In fact, additional results not reported here show that the affinity between Spanish men and French women is greater than the affinity between Spanish men and Italian, British, and German women. They also show that the affinity between Spanish women and French and Italian men is greater than the affinity between Spanish women and British and German men. These findings are consistent with the endogamy hypothesis, for French and Italians are closer culturally to Spaniards than are Britons and Germans (e.g. see World Values Study) ${ }^{11}$.

The exceptions to the endogamy hypothesis are the low odds-ratio for marriages between Spanish men and EU-15 women and the high odds-ratio for marriages between Spanish men and culturally more distant New Europeans. The two exceptions stem from the odds-ratios for Spanish men and women being different from one another. A consideration of the last hypothesis, H5, offers light on what may be happening. Indeed, the odds-ratios we observe for 2008-2009, when there were sizable populations of non-Europeans, EU-15 citizens, and New Europeans, are consistent with expectations grounded on homogamy and hypergamy. The marriage affinity between Spanish men and New European women is indeed greater than the marriage affinity between Spanish women and New European men. Also, the marriage affinity between Spanish men and Non Europeans is greater than the marriage affinity between Spanish women and Non European men. Inspection of microdata on 2008-

\footnotetext{
${ }^{10} \mathrm{We}$ computed the odds-ratio for Latin Americans separately from the rest of non-Europeans and the results confirm the results reported in the text. Since they are a very large group, their behavior drives the value for the odds-ratio computed for non-Europeans.

${ }^{11} \mathrm{We}$ lack information to adequately interpret the greater affinity that one finds between Spaniards and French compared to Spaniards and Italians. We can guess that, because of geographic proximity, French immigrants are a more socially diverse group of immigrants than are Italian immigrants, which would create more opportunities for intermarriage. Another possible explanation is that many French citizens who marry Spaniards are descendants of Spaniards.
} 
2009 marriages, by education and nationality, clarifies this finding.

Table 3 reveals that, regardless of nationality combination, the majority of marriages are homogamous with respect to education ${ }^{12}$. Since the average level of education among the EU-15 population is significantly higher than among the population from the new EU member states, one also finds that the highest percentage of homogamous marriages in the Spanish-EU15 category corresponds to couples where both have University education (46.4\% for Spanish women and 32.3\% for Spanish men). Meanwhile, the highest percentage of homogamous marriages in the Spanish-New EU category corresponds to couples with primary education or less (27.4\% for Spanish women, 35.4\% for Spanish men). Table 3 also shows that, contrary to traditional marriage patterns, hypogamous couples formed between a college-educated woman and a man with less than University studies are more prevalent than the hypergamous combination, both among binational marriages involving a European spouse and Spanish-Spanish couples. In other words, the odds that a man gets married to a more educated woman relative to the odds that he gets married to a less educated one are positive, whether we analyze marriages among Spaniards or between Spaniards and other nationality groupings. Therefore, the marriage microdata for 2008-2009 shed some light on our findings about the relative marriage affinity between different nationality groups by showing that marriage affinity between Spanish men and both New European and nonEuropean women is greater than marriage affinity between Spanish women and both New European and non-European men despite the fact that there is in-group and out-group educational hypogamy in marriage.

- Table 3 about here -

Hypogamy, however, cannot explain the observed nationality combinations in binational marriages, for if this were a strong and the only force underlying them, the marriage affinity between on average more educated Spanish women and on average less educated New Europeans and non-Europeans would be greater than the marriage affinity between Spanish women and on average better educated EU-15 men. The observed gender differences in nationality combinations in binational marriages are more congruent with an interpretation that stresses the combined forces of occupational/income hypergamy and culture. The marriage affinity between Spanish men and New European women is stronger than the

\footnotetext{
${ }^{12}$ The educational composition of marriages has been calculated by excluding cases where educational level is missing for one or both spouses. The large number of missing cases, around $30 \%$, might bias the results if their distribution across educational categories is not random.
} 
marriage affinity between Spanish women and New European men partly because New European women are overrepresented at the bottom of the occupational and income structure and Spanish men are overrepresented at higher occupational and income levels. The relative scarcity of women at higher occupational and income levels leads men at these levels to choose women at lower levels, which in turn moves the surplus of men at these lower levels to look for women at even lower levels until they get to the occupational and income positions where New European women are overrepresented (one could use an equivalent argument with women as the agents). Alternatively, or in combination with the structural argument, one could interpret the empirical findings by emphasizing the role of cultural change in advanced societies with respect to gender roles. In countries where they have reached high average levels of education, women become more assertive and reject traditional gender roles. While men's values also change on the average and become more gender-egalitarian, they remain conservative and more so than those of women from the same country. The marriage affinity of men from advanced economies and women from less developed countries thus might reflect their comparative advantage in the marriage market in terms of income and occupation in relation to foreign women with lower social status, and the fact that, on average, women from poorer societies comply with traditional gender roles more frequently than do women from the host society.

The cultural interpretation that we have just developed allows us to better evaluate the results concerning the endogamy hypothesis (H4). The endogamy hypothesis stresses the role of cultural similarity in marriage choice. Culture is a very broad concept that includes language, meaning systems, and values, among other dimensions. Endogamy certainly drives marriage choice: most marriages take place between members of the same nationality, which reflects the fact that, on average, people from the same country generally can communicate and share ways of interpreting the world to a greater extent than people from different countries. We also find that the marriage affinity between Spaniards and non-Europeans, who for a very large part come from Latin America, is highest, as one would expect. In the contemporary world, however, the overlap between nationality, world outlook, and values is no longer as great as it was in the past; furthermore, in an important dimension for marriage, which is that of values about gender roles, men and women in advanced societies have not changed at the same pace. In this context, international migration makes it possible for men and women from different countries who value traditional gender roles to meet and connect emotionally, even though they may differ in other aspects of their world outlook and may 
even experience difficulty in communicating. In this sense, the empirical findings in this paper uphold the role of culture in explaining both endogamy and gender departures from endogamy in contemporary advanced societies.

Overall, the analysis above confirms all our hypotheses, except for the one regarding trends in binational marriages by education. Some of the conclusions reached above by looking at simple marriage frequencies and bivariate tables for different nationality combinations get further support through multivariate multinomial logit models with marriage register data for 2008-2009. These microdata also allow us to move beyond tests of hypotheses into a more exploratory analysis concerning other socio-demographic characteristics of binational marriages. The models displayed in Table 4 provide us with a socio-demographic profile of Spaniards who married a foreign spouse in 2008-2009 distinguishing between EU-15, New EU and non EU spouses-, compared to Spaniards who married another Spaniard. Since our main concern is with the characteristics of binational marriages to Europeans, we present the results related to EU-15 and New Europeans only. The results of separate models for males and females are presented in Table $4^{13}$.

- Table 4 about here-

Columns 1 and 2 of Table 4 show that the odds to marry a European spouse increase with age, especially for men. For instance, Spanish males aged 40-49 are 86\% more likely to have married a EU-15 woman and 2.5 times more likely to have married a New EU woman than those aged 30-34. This pattern might be partly linked to the higher incidence of non-marital cohabitation at younger ages, particularly among European binational couples. The statistical results also show that marriage order is not associated to the odds of marrying EU-15 nationals but is associated to the odds of marrying New Europeans. Indeed, the odds of marrying New Europeans increase markedly for Spanish men and women who have been previously married ${ }^{14}$. Next, the statistical results offer insights into the socioeconomic status of the Spaniards who get married to nationals from EU-15 and the new EU member states.

\footnotetext{
${ }^{13}$ Missing values (26\%) are included in the models as a separate category for each independent variable, but the obtained coefficients are not shown in the table. We have re-estimated the regression models, this time excluding cases with missing values in the variable Educational Attainment. The coefficients do not differ significantly .

${ }^{14}$ When we run the same models without the variable Age, the odds of marrying EU-15 nationals increases also. There is indeed a small and statistically significant correlation between Age and Marriage Order.
} 
Generally speaking, the odds of marrying EU-15 nationals are higher among the better educated than among the lesser educated and among high-skilled than among low-skilled workers. This association is even stronger for Spanish women than for Spanish men. There is no association, however, between education and the odds of getting married to a New European among women and the odds that a Spanish man marries a New European woman are higher among the least educated than among the more educated. Also, there is no association between the Spaniards' job skills and the odds of getting married to New Europeans. These results for education and skills are consistent with homogamy and hypergamy principles. Since EU-15 nationals have higher average levels of education and job skills, it is to be expected that Spaniards who marry them have higher than average levels of education and job skills. Also since New Europeans have lower than average levels of education and job skills, it is to be expected that high educational levels and high skills play less of a role. The last rows in Table 4 further clarify this interpretation of the results. They show that, holding the Spaniards' levels of education and other variables constant, there is a positive association between being less educated than the EU-15 partner and the odds of getting married to one. This is certainly because the EU-15 nationals' levels of education are on average higher than those of Spaniards. Meanwhile, there is a positive association for Spanish men between being more educated than the New European wife and the odds of getting married to one. This would be in line with the fact that the New Europeans' levels of education are on average lower than the Spaniards'.

\section{Conclusions and discussion}

In the context of the broad transformation brought about by the process of economic, social and political European integration, this article has examined recent trends in what we have termed Euromarriages, marriages where one or two of the partners have a different European nationality from the one that corresponds to the country in which they get married. The evidence presented above shows that the elimination of barriers to movement, residence and work within the European Union has not translated into a dramatic increase in mixed European marriages in Spain. The rise in Euromarriages can be regarded as relatively modest, although the upward trend has intensified in recent years, primarily driven by Spanish males marrying Eastern European women. The article has relied on the nationality of foreigners who marry Spaniards to indirectly assess the role of "free movers" in recent trends in binational marriages in Spain. The analysis shows that traditional labour migrants are at 
least as relevant for these trends as "free movers". The article has explored new territory in the study of binational marriages between Europeans by focusing on the nationality composition of these marriages. This composition is relevant for the analysis of the emergence of new social groups in Europe resulting from the increase in the proportion of transnational ties. We find that in Spain, the most frequent type of binational marriage does not involve Europeans but, rather, Non-Europeans (mainly Latin Americans). When it comes to European binational marriages, the number of marriages between Spaniards and EU15 citizens slightly exceeds that between Spaniards and New Europeans. We find, however, significant gender contrasts, for binational marriages between Spaniards and EU15 generally involve Spanish women while binational marriages between Spaniards and New Europeans generally involve Spanish men. These findings are quite consistent with explanations of intermarriage that consider the role of stratified marriage markets, endogamy, and values.

Finally, the article has explored the socio-demographic profile of binational marriages. The educational profile of Spaniards marrying a EU-15 spouse differs significantly from that of Spaniards marrying a New EU spouse. Whereas highly educated Spaniards marry EU-15 citizens, it is lesser educated ones who tend to marry New EU citizens. This pattern is partly linked to the importance of homogamy in marriage decisions and to the fact that EU15 citizens display higher educational attainment than New EU citizens. Again, the high frequency of recent marriages between Spaniards and New EU citizens shows that while the effect of the Single Market on Euromarriages has been moderate, it has been felt among all Spanish social groups and not only among the highly educated ones, as the middle class bias of the recent sociology of European integration would lead one to expect.

In his introduction to Social Transnationalism, Mau (2007) stresses that before examining the consequences of the transnationalization of experience, we need to systematically collect empirical evidence and describe the characteristics of this transformation. This article advances in this direction. The trend analysis of Euromarriages in Spain reveals that the Single Market has contributed less to foster European intermarriage than has the enlargement to the relatively poorer countries of Central and Eastern Europe. Our findings highlight the crucial role of migration and hence local marriage market availability compared to that of increased interconnectivity or broadening of the marriage market limits. When Romanians came to Spain by the thousands, the number of marriages between Spaniards and Romanians increased considerably. A relatively equivalent growth in the number of migrants from EU-15 countries have in turn translated into a less important 
increase in the number of binational marriages between Spaniards and citizens from this group of countries.

Since opportunities of social contact are a major determinant of the frequency of binational marriages, one may ask about the indirect role played by membership in the European Union, the Single Market and Schengen in determining flows of people across borders and therefore the incidence of binational marriages. The demographic data presented above suggest that they are neither a necessary cause nor a sufficient one. There have been large flows of immigrants from North Africa and Latin America and a resulting increase in the number of binational marriages involving these nationalities. At the same time, neither membership in the European Union, nor the Single Market and Schengen have induced a dramatic increase in the settlement of EU-15 citizens in Spain and a concomitant rise in the number of binational marriages involving these nationalities. Meanwhile, the enlargement of the European Union to Central and Eastern Europe has triggered a large flow of traditional labour migrants from these countries to Spain, which has been followed by an immediate increase in the number of binational marriages between Spaniards and citizens from these countries. In this case, membership in the European Union has actually been a major contributing factor to growing migration across EU borders and to the recent increase in European intermarriage. The analysis above has also shown that the average level of education of Spaniards who marry Central and Eastern Europeans is lower than that of Spaniards marrying EU-15 citizens. Binational marriages in Spain therefore involve both lower class and middle class segments of the population. The literature suggests that the implications of lower class and middle class binational marriages for lifestyle and identification with Europe are different (Díez Medrano, 2008; Favell, 2008), just as the impact of traveling and migration varies according to the motivation for mobility and the social groups involved. This calls for further empirical research and also for a reassessment of the assumption that globalization impacts mainly on the lives of middle class, educated Europeans. 


\section{References}

Ackers L. 2004. Managing relationships in peripatetic careers: Scientific mobility in the European Union. Women's Studies International Forum 27(3): 189-201.

Arango J, Finotelli C. 2009. Past and future challenges of a Southern European migration regime: the Spanish case. IDEA Working paper 8. http://www.idea6fp.uw.edu.pl/pliki/WP8_Spain.pdf

Blau PM. 1977. Inequality and Heterogeneity. New York: The Free Press.

Blau PM, Schwartz JE. 1984. Crosscutting Social Circles: Testing a Macrostructural Theory of Intergroup Relations. New York: Academic Press

Blackwell DL. 1998. Marital homogamy in the United States: The influence of individual and paternal education, Social Science Research, 27 (2): 159-188.

Braun, M, Recchi E. 2008. Interethnic partnerships of western Europeans: between preferences and opportunities. OBETS: Revista de Ciencias Sociales 1: 73-89.

Burchinal, L. 1964. The premarital dyad and love involvement. In Harold T. Christensen (ed.) Handbook of Marriage and the Family. Chicago: Rand McNally.

Calligaro O. 2011. Negotiating Europe: EU Promotion of Europeanness and Non-Institutional Actors since the 1950s. Unpublished Dissertation. European University Institute, Florence.

Cortina C, Bueno X, Castro-Martín, T. 2010 ¿Modelos familiares de aquí o de allá? Pautas de cohabitación entre las mujeres latinoamericanas en España. América Latina Hoy, 55: 61-84.

Cortina C, Esteve A, Domingo A. 2008. Marriage patterns of foreign born population in a new country of immigration: the case of Spain. International Migration Review, 42(4): 877-902.

Díez Medrano J. 2008. Europeanization and the Emergence of a European Society. IBEI Working Paper, 2008/12.

Díez Medrano J. 2010. An Emergent European Middle Class. Working Paper 12. Kfg "The Transformative Power of Europe". Freie Universität Berlin.

Díez Medrano J. 2011. The Present and Future of Social Classes. In Adrian Favell and Virginie Guiraudon (eds.) The Sociology of the European Union. Oxford: Palgrave.

Domínguez M, Castro-Martín T. 2008. Women's changing socioeconomic position and union formation in Spain and Portugal. Demographic Research 19-41: 1513-1550. DOI: 10.4054/DemRes.2008.19.41.

Esping-Andersen G. 2009. The Incomplete Revolution: Adapting to Women's New Roles.

Cambridge: Polity Press.

Esteve A, Cortina C. 2006. Changes in educational assortative mating in contemporary Spain. Demographic Research 14-17: 405-428.

Esteve A, Cortina C. 2011. Trayectorias conyugales de los inmigrantes internacionales en España. Documents d'Anàlisi Geogràfica (DAG), 57(3):467-491.

Favell A. 2008. Eurostars and Eurocities: Free Movement and Mobility in an Integrating Europe. Oxford: Blackwell.

Favell A., Guiraudon, V. (eds). 2011. Sociology of the European Union. Basingstoke: Palgrave Macmillan.

Fligstein N. 2008. Euroclash. The EU, European Identity, and the Future of Europe. Oxford: Oxford University Press. 
Gabel M. 1998. Interests and Integration: Market Liberalization, Public Opinion, and European Union. Ann Arbor: University of Michigan Press.

Gaspar S. 2008. Towards a definition of European intra-marriage as a new social phenomenon. Centro de investigação e estudos de sociologia (CIES) e-Working Paper 46/2008.

Gaspar S. 2009. Mixed marriages between European free movers. Centro de investigação e estudos de sociologia (CIES) e-Working Paper 65/2009.

Georgakakis D. 2012. Le champ de 1' Eurocratie. Une sociologie politique du personnel de l' UE, Paris: Economica.

Glowsky D. 2011. Globale Partnerwahl. Soziale Ungleichheit als Motor transnationaler Heiratsentscheidungen. VS Verlag für Sozialwissenschaften, Wiesbaden.

González-Ferrer A. 2006. Who do immigrants marry? partner's choice among single immigrants in Germany. European Sociological Review 22(2): 171-185. DOI: 10.1093/esr/jci050.

Gordon M. 1964. Assimilation in American Life. New York: Oxford University Press.

Haandrikman K, Hutter I. 2012. 'That's a different kind of person'- Spatial connotations and partner choice. Population, Space and Place 18(3): 241-259. DOI: 10.1002/psp.661.

Inglehart R. 1977. The Silent Revolution: Changing Values and Political Styles among Western Publics. Princeton, NJ: Princeton University Press.

Inglehart R, Norris P. 2003. Rising Tide: Gender Equality and Cultural Change Around the World. Cambridge University Press.

Kalmijn M. 1998. Intermarriage and homogamy: Causes, patterns, trends. Annual Review of Sociology 24 (1): 395-421.

Kalmijn M, Van Tubergen F. 2007. Ethnic intermarriage in the Netherlands: Confirmation and refutation of accepted insights. European Journal of Population Studies 22(4): 371-397. DOI: 10.1007/s10680-006-9105-3.

Koelet S. et al. 2011. Bi-national marriages between European citizens: From intermarriage to intramarriage? Paper presented at the IUSSP Seminar on Global Perspectives on Marriage and International Migration, Seoul (Korea).

Lanzieri G. 2011. Comparison of recent trends of international marriages and divorces in European countries. Paper presented at the IUSSP Seminar on Global Perspectives on Marriage and International Migration, Seoul (Korea).

Lieberson S, Waters MC. 1988. From Many Strands: Ethnic and Racial Groups in Contemporary America. New York: Russell Sage Foundation.

Mare R. 1991. Five decades of educational assortative mating. American Sociological Review 56(1): 15-32

Mau S. 2007. Transnationale Vergesellschaftung. Die Entgrenzung sozialer Lebenswelten. Frankfurt: Campus Verlag.

Niedomysl T, Östh J, van Ham M. 2010. The globalisation of marriage fields: The Swedish case. Journal of Ethnic and Migration Studies 36(7): 1119-1138. DOI: 10.1080/13691830903488184.

OECD. 2010. International Migration Outlook. SOPEMI 2010. OECD Publishing, Paris.

Qian Z, Lichter DT. 2007. Social boundaries and marital assimilation: Interpreting trends in racial and ethnic intermarriage. American Sociological Review 72: 68-94. DOI: 10.1177/000312240707200104. 
Recchi E. 2005. Migrants and Europeans: An outline of the free movement of persons in the EU. The Academy for Migration Studies in Denmark (AMID) Working Paper Series 38.

Recchi E, Favell A. 2009. Pioneers of European Integration: Citizenship and Mobility in the EU. Cheltenham: Edward Elgar.

Reher D, Requena M. 2009. The National Immigrant Survey of Spain. A new data source for migration studies in Europe. Demographic Research 20-12. DOI: 10.4054/DemRes.2009.20.12.

Sánchez-Domínguez M, de Valk H, Reher D. 2011. Estrategias matrimoniales de los inmigrantes en España. Revista Internacional de Sociología 69(M1): 139-166.

Schoen R, Wooldredge J. 1989. Marriage choices in North Carolina and Virginia, 1969-71 and 197981. Journal of Marriage and the Family 51: 465-481.

Schrödter JH. 2006. Binationale Ehen in Deutschland. Wirtschaft und Statistik 4: 419-431.

Stanek M. 2009. Patterns of Romanian and Bulgarian migration to Spain. Europe-Asia Studies 61(9): 1627-1644. DOI: 10.1080/09668130903209160.

Timberlake JM, Heuveline P. 2005. Changes in nonmarital cohabitation and the family structure experiences of children across 17 countries. Sociological Studies of Children and Youth 10: 257278. DOI: $10.1016 / \mathrm{S} 1537-4661(04) 10013-5$.

Varro G. 1995. Les couple mixtes et leurs enfants en France et en Allemagne. Paris: Armand Collin.

World Tourism Organisation. 2001. Tourism Highlights 2001 Edition. http://mkt.unwto.org/sites/all/files/docpdf/unwtohighlights11enlr_1.pdf.

Zelditch M. 1964. Family, marriage and kinship. In Farris R (ed.) Handbook of Modern Sociology. Chicago: Rand McNally. 


\section{TABLES AND FIGURES}

Figure 1. Stock of foreigners according to nationality group. Spain, 1998-2009

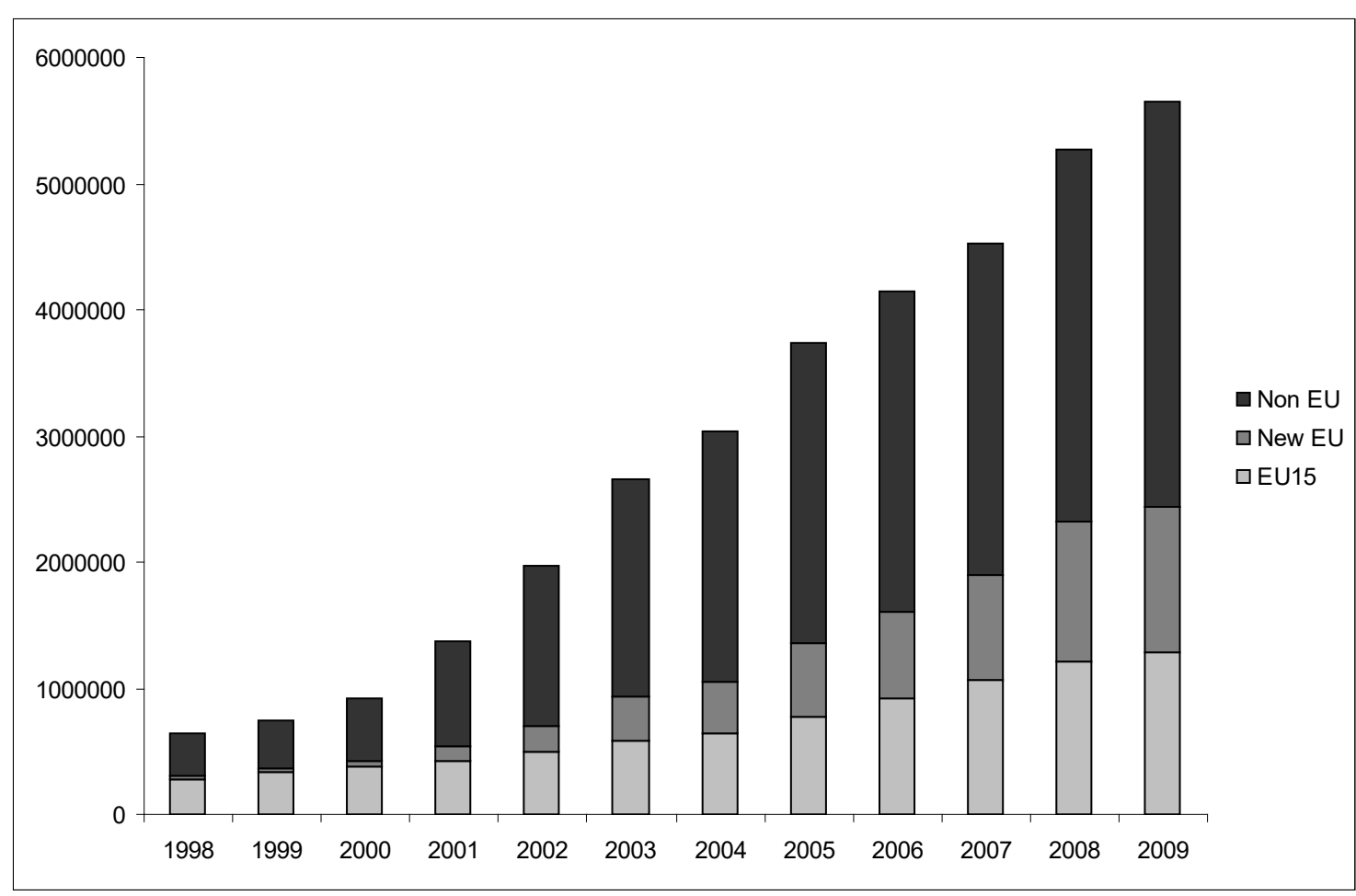

Source: Population register, Spanish Statistical Institute. 
Table 1. Distribution of marriages according to spouses' nationality. Spain, 1990-2009

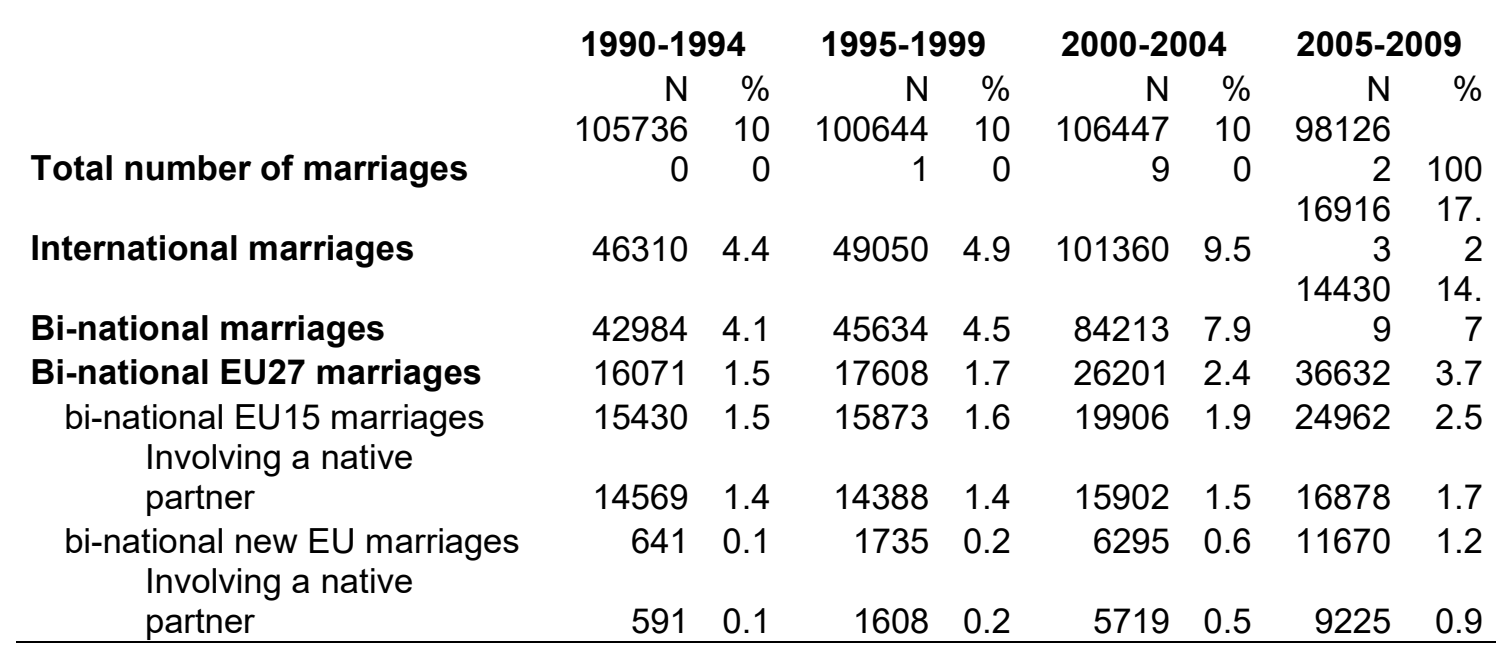

Source: Vital Statistics, Spanish Statistical Institute 
Figure 2. Trends in the number of European binational marriages by sex and nationality group of the foreign spouse. Spain, 1989-2009

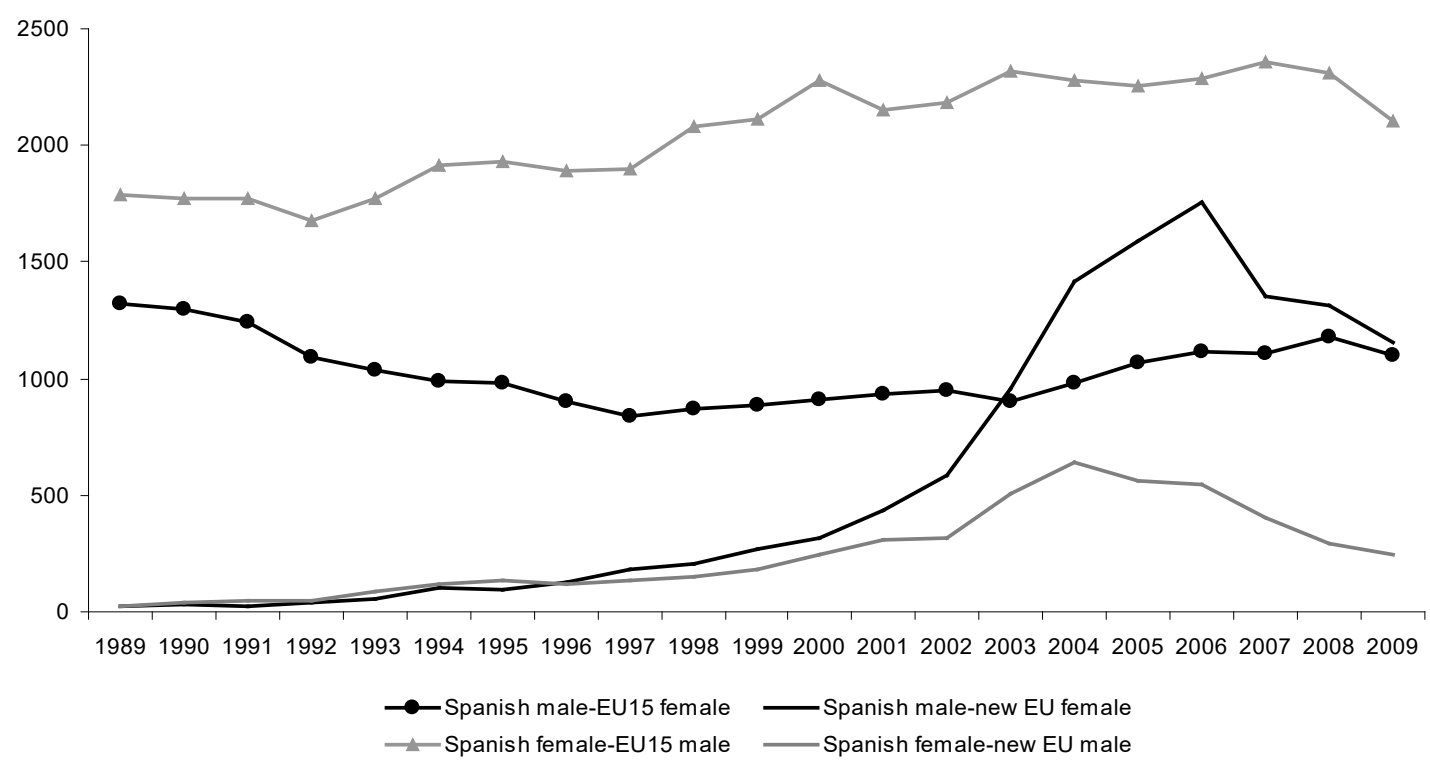

Source: Vital Statistics, Spanish Statistical Institute 
Table 2. Trends in odds ratios of European binational intermarriages by sex and nationality group of the foreign spouse. Spain, 1990-2009

\begin{tabular}{ccccccc} 
& $\begin{array}{c}\text { Native men } \\
\text { EU15 } \\
\text { women }\end{array}$ & $\begin{array}{c}\text { Native men } \\
\text { new EU } \\
\text { women }\end{array}$ & $\begin{array}{c}\text { Native men } \\
\text { non EU } \\
\text { women }\end{array}$ & $\begin{array}{c}\text { Native } \\
\text { women } \\
\text { EU15 men }\end{array}$ & $\begin{array}{c}\text { Native } \\
\text { women new } \\
\text { EU men }\end{array}$ & $\begin{array}{c}\text { Native } \\
\text { women non } \\
\text { EU men }\end{array}$ \\
\cline { 2 - 7 } $1990-1991$ & 0.13 & 0.05 & 0.11 & 0.15 & 0.04 & 0.10 \\
$2000-2001$ & 0.06 & 0.06 & 0.11 & 0.14 & 0.06 & 0.08 \\
$2008-2009$ & 0.07 & 0.19 & 0.25 & 0.17 & 0.08 & 0.21 \\
\hline
\end{tabular}

Source: own elaboration from Vital Statistics, Spanish Statistical Institute 
Table 3. Educational composition of marriages by nationality group, 2008-2009 (\%)

\begin{tabular}{|c|c|c|c|c|c|c|c|}
\hline & $\begin{array}{r}\text { Both } \\
\text { Spouses } \\
\text { Primary } \\
\text { Education } \\
\text { or Less } \\
\end{array}$ & $\begin{array}{r}\text { Both } \\
\text { Spouse } \\
\text { Secondary } \\
\text { studies } \\
\end{array}$ & $\begin{array}{r}\text { Both } \\
\text { Spouses } \\
\text { University } \\
\text { Studies } \\
\end{array}$ & $\begin{array}{r}\text { Man } \\
\text { University } \\
\text { Studies- } \\
\text { Women } \\
\text { less than } \\
\text { University } \\
\end{array}$ & $\begin{array}{r}\text { Woman } \\
\text { University } \\
\text { Studies- } \\
\text { Man less } \\
\text { than } \\
\text { University }\end{array}$ & $\begin{array}{r}\text { Other } \\
\text { combinations } \\
\end{array}$ & Total \\
\hline Spanish male-Spanish female & 18.4 & 18.2 & 20.8 & 6.8 & 18.3 & 17.6 & 100 \\
\hline Spanish male-EU15 female & 12.5 & 15.4 & 32.3 & 8.7 & 17.7 & 13.5 & 100 \\
\hline Spanish male-new EU female & 35.4 & 13.6 & 9.6 & 7.5 & 11.7 & 22.2 & 100 \\
\hline Spanish female - EU15 male & 8.9 & 12.6 & 46.4 & 8.4 & 15.5 & 8.2 & 100 \\
\hline Spanish female-new EU male & 27.4 & 17.3 & 7.2 & 5.3 & 19.9 & 22.9 & 100 \\
\hline
\end{tabular}

Note 1: age range 20-49, all marriage orders.

Note 2: cases with missing values are excluded from calculations.

Source: own elaboration from Vital Statistics, Spanish Statistical Institute 
Table 4. Results from the multinomial regression models of the probability of Spaniards married in 2008-2009 to have a foreign spouse instead of a native spouse

Males

$\begin{array}{ll}\text { Age } & \\ & \\ & 20-24 \\ & 25-29 \\ & 30-34 \text { (ref.) } \\ & 35-39 \\ & 40-49\end{array}$

Marriage order

First marriage

Second + marriage (ref.)

Educational level

Less than primary

Primary completed (ref.)

Secondary completed

University

Occupation

$$
\begin{aligned}
& \text { highly skilled } \\
& \text { non highly skilled (ref.) }
\end{aligned}
$$

Educational homogamy

Educational homogamy

Man lower education

Man higher education (ref.)

-2 Log likelihood

$\begin{array}{rrr}\begin{array}{r}\text { Wife } \\ \text { from }\end{array} & \begin{array}{r}\text { Wife } \\ \text { from } \\ \text { new }\end{array} & \begin{array}{r}\text { Wife } \\ \text { from }\end{array} \\ \text { EU15 } & \text { non } \\ & \text { EU } & \text { EU } \\ \operatorname{Exp}(B) & \operatorname{Exp}(\mathrm{B}) & \operatorname{Exp}(\mathrm{B})\end{array}$

$\begin{array}{llllll}1.07 & & 1.00 & & 2.16 & * * \\ 0.69 & * * & 0.62 & * * & 0.91 & * * \\ 1.00 & & 1.00 & & 1.00 & \\ 1.48 & * * & 1.80 & * * & 1.76 & * * \\ 1.86 & * * & 2.49 & * * & 2.63 & * *\end{array}$

0.93

1.00

$0.52 *$

1.00

0.44

1.00

1.02

1.00

$1.52 *$

1.16

1.00

1.57

1.00

$0.54 * *$

$1.73 * *$

$0.36 * *$

$1.42 * * \quad 0.85$

1.00

1.00

1.17

1.36

1.00

0.52

0.36

1.00

5570.0

306939

Note: age range 20-49.

$* \mathrm{p}<.01, * * \mathrm{p}<.001$

Source: Vital Statistics, Spanish Statistical Institute

\section{Females}

$\begin{array}{r}\text { Husband } \\ \text { from }\end{array}$
EU15
$\operatorname{Exp}(\mathrm{B})$

$\begin{array}{rr}\begin{array}{r}\text { Husband } \\ \text { from }\end{array} & \begin{array}{r}\text { Husband } \\ \text { from }\end{array} \\ \text { new EU } & \text { non EU } \\ & \operatorname{Exp}(B)\end{array}$

$\begin{array}{llllll}0.48 & * * & 1.55 & & 2.79 & * * \\ 0.55 & * * & 0.80 & * & 0.93 & * \\ 1.00 & & 1.00 & & 1.00 & \\ 1.31 & * * & 1.21 & & 1.47 & * * \\ 1.38 & * * & 1.17 & & 1.58 & * *\end{array}$

1.14

$0.54 * * \quad 0.44 \quad * *$

1.00

1.00

1.05

1.18

$1.96 * *$

1.00

$0.66 * *$

$0.49 * *$

$1.60 * * \quad 0.63$

0.56

$0.79 * *$

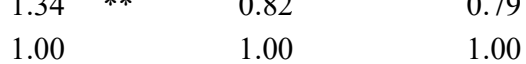

$0.74 * * \quad 0.76$

1.04

$0.36 * * \quad 1.29$

$1.37 * *$

1.00

1.00

1.00 